\title{
The Impacts of the Taiwan Issue on Sino-US Relations
}

\author{
Hao Xie \\ Shanghai-Hongkong Development Institute, Fudan University, Shanghai, China \\ Email: xiehao1978@hotmail.com
}

Received 7 July 2014; revised 11 August 2014; accepted 30 August 2014

Copyright (c) 2014 by author and Scientific Research Publishing Inc.

This work is licensed under the Creative Commons Attribution International License (CC BY). http://creativecommons.org/licenses/by/4.0/

\begin{abstract}
The Sino-US relations can be regarded as one of the most important bilateral relations in the world, and the Taiwan issue is the core of the relations. The main purpose of this paper is to analyze the impacts of the Taiwan issue on the Sino-US relations. These impacts are analyzed in the following four aspects: 1) the attitude of the US to the Taiwan independence forces; 2) the adjustment of global strategic objectives of the US; 3) the rise of China and the adjustment of the US's China strategy; 4) the factors of Taiwan issue influencing on pattern of common interests of China and the US.
\end{abstract}

\section{Keywords}

China, The US, Sino-US Relations, Taiwan

\section{Introduction}

Since China carried out the reform and opening-up policy in 1978, it has been gradually integrated into the Western-dominated international community. Although there are fundamental differences in basic beliefs about the nature of man and society between China and the US, and these differences make it difficult for Chinese to understand the US, and vice versa (Shambaugh, 1988); there is still constantly increasing level of interdependence between China and the US. If China and the US deal with their relationship with a long-term strategic vision, and actively seek common interests in different fields, probably, the relations between them will be stable, though they still need to consider their own interests at the same time.

However, the US, the only superpower in the world, has to face the fact that China is becoming a rising power in existing international system. The world history has witnessed many cases that the hegemonic powers would try to block or attack the rising power for safeguarding their own power. National interest can be regarded as a basic driving force behind the international activities of a country, especially when the country deals with rela- 
tions with other countries in the international community. This is helpful for understanding the analysis of the Sino-US relations from the perspective of the Taiwan issue.

\section{The Attitude of the US to the Taiwan Independence Forces}

After the Cold War and the disintegration of the Soviet Union, China and the US had partly lost the base of cooperation. However, a large number of facts have proved that this opinion is not totally correct especially after the 9/11 event. In fact, China and the US have broad common interests in different fields. For example, the 9/11 event gave China and the US a new opportunity to seek new common interests in security area and they could cooperate with each other to fight against terrorism.

The 9/11 event can be regarded as a watershed event in Bush administration's China policy. The China policy of every previous government of the US had a feature that, at the beginning of the presidential term, the American administration take a hard-line policy toward China but then adopt a pragmatic and rational attitude to the Sino-US relations. For instance, when George W. Bush just became the president of the US in 2001, he took the hard-line policy toward China and pro-Taiwan policy. Bush administration undermined the tradition that only sold defensive weapons to Taiwan, via intensifying military cooperation with Taiwan. On 24 April 2001, President Bush said that the US would do "whatever it took to help Taiwan defend herself" in the event of attack by China (Wallace, 2001). It was good news for Democratic Progressive Party (DPP), the representative of Taiwan separatist force, and it could be seen as a kind of support for them. Therefore, the Sino-US relations has been tense since the Bush administration publicly declared that opinion.

After the 9/11 event, some officials in the Bush administration believed that the American campaign to fight terrorism should reinforce cooperative relations with US allies in East Asia and create incentives for accommodating relations with China (Krauss, 2003). In October 2001, although the domestic situation of the US was very tense, Bush still went to Shanghai to participate in Informal APEC Economic Leaders' Meetings (IAELM) and held bilateral meeting with Chinese President Jiang Zemin. Bush and President Jiang were both willing to build constructive and cooperative China-US relations.

When US Vice President Dick Cheney met with Chinese Vice President Hu Jintao in the May 2002, he expressed that the American administration did not support Taiwan independence and also did not support the development of Taiwan separatist force. When Chinese President Jiang Zemin visited the US in October 2002, Bush said that one-China policy means that the issue ought to be resolved peacefully and we've got influence with some in the region; we intend to make sure that the issue is resolved peacefully-and that includes making it clear that we do not support independence (The White House, 2002).

After September 2003, Chen Shui-bian, The President of the Republic of China, launched the constitutional referendum which could be seen as the Taiwan independence timetable. This leaded to sustained tension in the Taiwan Strait and brought the relations between China Mainland and Taiwan to the brink of danger. The Chinese government explicitly asked the American administration to stop the Taiwan independence provocation. As a response, the US administration sent Michael Green, who was the senior director for East Asian affairs of the US National Security Council, to Taiwan with President Bush's letter to put pressure on Chen Shui-bian. After that, he came to Beijing to communicate with Chinese government. Because of failing to dissuade the Taiwan independence movement led by Chen Shui-bian, the US administration had to increase the pressure on Chen Shui-bian. Richard Boucher, US State Department spokesperson, said that Washington would be opposed to any referenda that would change Taiwan's status or move towards independence (Boucher, 2003). A few years later, Ma Ying-jeou from Kuomintang won presidential elections in 2008 and 2012, which relieved the cross-strain relations between Mainland China and Taiwan.

From these facts it can be seen that China and the US actually have established dialogue mechanism and crisis management mechanism. This means that the Chinese government and the US government are able to communicate with each other in time when they encounter significant problems, such as the Taiwan issue. This demonstrates that the ability of China and the US to deal with frictions under control.

It is important to note that some measures adopted by American administration have positive impacts on stabilizing the situation of the Taiwan Strait and promoting the development of the Sino-US relations. However, the slight adjustment of Taiwan policy of the US does not mean that the US government intends to change its fundamental principles. On the one hand, the US has to take some measures to constrain the development of Taiwan independence forces and not allow Taiwan authorities to go too far down the path of separatism; on the 
other hand, the US still sells arms to Taiwan and provides protection for it. By strengthening its military alliance with Japan, the US wants to include Taiwan in its scope. What the US does on the Taiwan issue, in some extent, can be understood because it worries about the unstable aspects of a non-democratic China. In this sense, this is the continuation of the US's policy toward Taiwan.

\section{The Adjustment of Global Strategic Objectives of the US}

The Taiwan policy of the US can be regarded as a part of its China policy, which can be seen as an important part of its global strategy. After the Zhenbao Island incident, the general Soviet policy toward China consisted of denunciations, criticism, threats, and blandishment (Robinson, 1982). So, Beijing and Washington had submerged their differences because of their common interest of confronting a common adversary, the Soviet Union (Calabrese, 1992), and they were able to find the base of strategic cooperation. However, they did not need help from each other anymore in this field after the end of the Cold War. Thus, the Sino-US relations have been changed. Some officials of the US thought that China could be considered as a strategic adversary of the US. Some anti-China forces in the US rediscovered the value of Taiwan issue and they were trying to contain China by playing the Taiwan card.

After the 9/11 terrorist attacks, the US administration has immediately adjusted its global strategy and has shifted its focus on anti-terrorism activities. Under this circumstance, anti-terrorism has been considered as the top priority on global strategy by the government of the US. The American government holds that the proliferation of weapons of mass destruction is the major threat to the survival and security of the US. Once terrorist forces obtain these weapons, the consequences are unthinkable. Therefore, anti-terrorism and non-proliferation are the core interests of the US. In order to achieve this objective, the US needs to cooperate with China in many fields. It is obvious that the anti-terrorism activities actually promote the improvement of the Sino-US relations.

The wars in Iraq and Afghanistan triggered anti-US rallies in the Muslim world. The US government hoped that China could play a greater role on the North Korea and Iran nuclear issues. Therefore, because of the adjustment of the global strategic objectives of the US and its increased demand for China, the US enhanced its relations with China. Since China and the US decided to establish the diplomatic relations in 1972, the USTaiwan relationship has been subordinate to the Sino-US relations. Every time when the US plans to readjust its policy towards Taiwan, it has to seriously consider its relations with China. According to Robert S. Ross, during the war in Afghanistan, the US minimized involvement by its NATO allies and the US would be no more interested in cooperation with Taiwan in the event of a US-China war in the Taiwan Strait (Ross, 2002).

\section{The Rise of China and the Adjustment of the China Strategy of the US}

The US has realized that the tectonic plates of power that have characterized Asia for half a century are shifting, and China may be returning to its traditional role as the central actor in Asia (Shambaugh, 2006). Although the relationship between China and the US is stable now, the US still cannot regard China as its real friend. Ideological differences between them are one of the reasons. Nevertheless, as Liu puts it, ideology is playing an increasingly insignificant role in China's relations with foreign countries (Chen, 2005). Another important reason is the rise of China.

Understanding China as a rising power in the world has become a difficult question for the US government, and Western and Asian fears of a potential "China threat" are driven largely by the assumption that continued Chinese economic growth eventually provide the foundation for a substantial increase in Chinese military power, and by uncertainty how China is likely to use this power in the future (Saunders, 2000). The government of the US worries about the development direction of China. Some officials of the US with a realist perspective think that China represents an explicit challenge to the position of the US in Asia and the world (Saunders, 2000).

The US has misgivings about the rise of China, so it has increased vigilance against a possible threat from China. After Bush became the President of the US, he launched to promote the capability of military coordination with its alliances in the Asia-Pacific region such as Japan, Korea and Australia. The US regarded the US-Japan alliance as the key point of its strategic position in Asia-Pacific region. In February 2005, the US announced that it would include Taiwan into the scope of US-Japan security cooperation and it also attempted to extend its missile defense system to cover Taiwan. The US and Japan issued a joint statement after the one-day consultation that for the first time included the peaceful resolution of issues concerning the Taiwan Strait through dialogue (Yuan, 2005). The China’s Foreign Ministry spokesman expressed that Beijing resolutely op- 
poses the US and Japan in issuing any bilateral document concerning China's Taiwan, which meddles in the internal affairs of China, and hurts China's sovereignty (Yuan, 2005). For further confronting China's rise, on Nov. 17, 2011 US President Barack Obama delivered a speech in the Australian Parliament, and proposed the "return-to-Asia” strategy. In his speech, President Obama stressed that let there be no doubt: in the Asia-Pacific in the 21st century, the US of America is all in (Feller, 2011). Although President Obama did not mention the Taiwan issue, in the geopolitical considerations behind the "return-to-Asia” strategy, Taiwan will undoubtedly occupy an important position, and would produce impacts on Sino-US relations that could not be ignored.

In today's era of globalization, both China and the US have many common interests in regional affairs, global security and their bilateral relations, so it is possible and necessary for them to cooperate with each other. China's position in the US global strategy is significantly increasing, especially in economic field. Actually, it is a simplistic view to regard China as a strategic competitor. The government of the US already has new understanding of complexity and importance of the Sino-US relations. China has the ability to help the US to prevent the proliferation of weapons of mass destruction and fight against terrorism in the world, though China has the potential to challenge the global status of the US.

Robert B. Zoellick, former Deputy Secretary of State of the US, stated that we need to urge China to become a responsible stakeholder in that system (Zoellick, 2005), the international system. It shows that China and the US have built a new framework for the development of their relationship. The complex relations between them include seeking mutual cooperation and guarding against each other. However, since the US has qualified China as a stakeholder and asked China to be a responsible member of the international community, it should also honor the promise it has made to China that it does not support Taiwan independence (Huang, 2006).

If the content of the American strategy towards China includes containing China, Taiwan will be its trump card. However, the effect of Taiwan has to not only be subordinated to the global strategic objectives of the US, but be limited by the development of Sino-US relations. Thus, the development of the Sino-US relations fundamentally constrains the evolution of Taiwan issue and also restricts American policy toward Taiwan. Although there are some conflicts and differences between China and the US, many facts have proved that cooperation is the mainstream of the Sino-US relations now. With the rise of China, both China and the US will broaden the scope of cooperation and will strengthen coordination, and they can find out more potential for cooperation in the future.

\section{The Factors of Taiwan Issue Influencing on Pattern of Common Interests of China and the US}

The Taiwan issue is a historical problem which is left over by China's civil war. Chinese government believes that the Taiwan issue is Chinese internal affair, so it cannot brook direct or indirect interference by any foreign forces. Both Cairo Declaration issued by China, the US and the United Kingdom in December 1943 and the Potsdam Proclamation signed by China, the US, the United Kingdom and the Soviet Union in 1945 announced that all territories, including Taiwan, occupied by Japan before the end of the Second World War should be returned to China. On 25 October 1945, the Japanese government completed the returning of sovereignty of Taiwan to China. Thus, Taiwan is an inalienable part of China and it has been proven through history. However, political behavior of states is not always dominated by rationality. In many cases, the political behavior will be irrational due to national interests. This is one of important reasons why the Taiwan issue can be regarded as a barometer for Sino-US relations.

As the superpower in the world after the Cold War, the US seeks its national interests on a global scale, and Taiwan becomes an important American agent which is able to help the US to obtain strategic interests in the Asia-Pacific region. In the system of national interests, the status of various interests of countries is not immutable. At different periods of history, the core interests of different countries keep changing due to changes in international situations. The Taiwan issue is the core interest of China, and Chinese leaders believe that reunification of China is their historical mission. With constant enhancement of its comprehensive strength, China should widely participate in international affairs, actively integrate into the international community and develop friendly and cooperation relation with other countries in different fields. Thus, China is likely to continue to pursue its current external policy, marked by overall caution, pragmatism and an emphasis on a peaceful regional environment so as to permit China's modernization program to succeed (Hieronymi, 2004). The Sino-US relations can be seen as one of the most important bilateral relations in the world. If both sides intend to promote their relations, they should not challenge each other's core interests. If the government of the US continues to 
challenge China's core interests, especially about the Taiwan issue, and does not comply with the promise of one-China policy, the relationship between China and the US is bound to inevitably face setback.

Obviously, striving for the peaceful reunification of China accords with the interests of China, the US and other Asia-Pacific countries. Chinese people are reluctant to see the horrible situation where they have to fight their compatriots across the Taiwan Strait. In fact, leaders in Beijing undoubtedly will be preoccupied with daunting domestic problems and unwilling to see a tense cross-Strait situation, which would distract them from their domestic agenda (Cheng, 2005). Maintaining good surrounding environment and stable Sino-US relations is very important for the development and modernization of China. From Taiwan's perspective, the war means a tremendous, absolute, comprehensive disaster which will destroy its painstaking efforts after the China's Civil War ended in 1949. From the Asia-Pacific countries' perspective, maintaining stability in the Taiwan Strait and maintain East Asia security is common aspiration of people in East Asian region. From the American view, the US and its allies will have to pay a high price for this possible war across the Taiwan Strait in the future. Therefore, the Sino-US relations will decide and contain the development of relationship between the US and Taiwan.

With the peaceful rise of China and the decrease of Taiwan's international space, the common interests between China and the US will keep on increasing, but the common interest between the US and Taiwan will be made smaller than before. A divided Taiwan does not have enough special interest for the US if China can promote economic development and achieve democratization. Maintaining peace and stability in the Taiwan Straits aligns with the common interests of China and the US, so the American government should not send any wrong signal to the Taiwan independence force.

The current American policy toward China will continue for quite a long time if the Chinese government still adopts its open policy and promotes democracy. On the current international situation, this policy in some extent will be effective and will lead to peaceful and stable relations between the US and China. Thus, this policy is very pragmatic. The US should realize that so long as Beijing eschews the use of force and works peacefully to adapt to and shape the future international system, the most destabilizing consequences of growing Chinese power will be minimized (Swaine, 2000). Actually, both China and the US do not want to use military means to resolve the Taiwan issue. It should be noted that China and the US have common interest in many aspects but it does not mean that the US can challenge the core interest of China.

Since China and the US established the formal diplomatic relations in 1979, both Chinese leaders and the leaders of the US have been trying to use different ways to promote the Sino-US relations. Without doubt, they have already yielded fruitful results in various fields of cooperation which can lead to a better understanding of the Taiwan issue. In fact, in many fields they have reached consensus which is based on common strategies and interests. They are willing to promote world peace and development of the Asia-Pacific region and try to enhance economic cooperation and seek common development and prosperity.

\section{Conclusion}

The US strategy toward China is one of the most important factors which can influence the development of Sino-US relations and US strategy toward China is subordinate to its global strategy. China's modernization is a long-term undertaking. In the process of reform, opening-up and modernization, China needs to maintain good bilateral relations with the US. The government of the US would emphasize particularly different aspects or fields, and thus, it could lead to volatility in the US strategy toward China. From the current international situation, the US is having increasing demand of cooperation with China, so the Sino-US relations can be seen as constructive and cooperative.

It can be expected that the global strategy of the US will not be fundamentally changed in the next ten or twenty years. The government of the US realizes that it needs to prepare for and fight a long-duration war against terrorism. At present the war against radical Islamic forces has been going for many years, but the threat of terrorism has not diminished. In addition, the situation of preventing the proliferation of nuclear weapons is becoming growingly complex due to the Iranian nuclear issue and the North Korea nuclear issue. The government of the US clearly knows that it will take a long time to resolve all of these problems.

On the one hand, some officials in the government of the US still hold negative views on the impacts of China's development. They guard against China's development because they regard China as future threat to the US. However, on the other hand, China's development has also made the US government realize the importance of cooperation between China and the US in the international community. 
The Chinese government proclaims to the world that China will follow the road of peaceful development and would never seek hegemony. If the Chinese government can prove that it will not change the existing international order which is mainly dominated by the US, the US strategy towards China will be more rational.

The Taiwan issue is inextricably linked to the development of Sino-US relations and probably is the only possibility that leads to military conflicts between China and the US. In fact, due to their strategies, maintaining peace and stability across the Taiwan Strait can help Beijing and Washington to obtain common interests on the Taiwan issue. However, the Taiwan independence forces gravely threaten the common interests of China and the US. Both of them should ensure timely communication and cannot give any opportunity to the Taiwan independence forces which are able to destabilize the stable situation of the Taiwan issue.

A new scene of relations among big powers can be seen after the Cold War and the main theme of the relations is seeking win-win cooperation. The interests and relations of big powers are so complicated that we cannot say the relationship among big powers is completely antagonistic. Actually, they are seeking cooperation in many aspects and the relationship between China and the US is also in the frame of relations among big powers. In the foreseeable future, both China and the US will not have strong motivation to break through the framework of relations among big powers.

After the 9/11 event, international security situation has become more complex and non-traditional security threat is now growing. Terrorism, the proliferation of weapons of mass destruction, energy security, financial security, infectious diseases, environmental degradation and other threats become growingly serious. They endanger society and public interests of mankind. In respond to these threats, every country, especially major powers in the world should cooperate with each other. China and the US are able to find common interests and share broad space for cooperation. Because of the increase of interdependence and common interests, the major powers are willing to seek cooperation but not confrontation and conflict. In the future, economic globalization and world multi-polarization can be regarded as a trend which will be conducive to the relationship between China and the US.

\section{References}

Boucher, R. (2003). Daily Press Briefing. http://2001-2009.state.gov/r/pa/prs/dpb/2003/26776.htm

Calabrese, J. (1992). Peaceful or Dangerous Collaborators? China’s Relations with the Gulf Countries. Pacific Affairs, 65, 471-485. http://dx.doi.org/10.2307/2760315

Chen, W. (2005). Leadership in a Changing China. Gordonsville: Palgrave Macmillan. http://dx.doi.org/10.1057/9781403980397

Cheng, T. (2005). China under Hu Jintao: Opportunities, Dangers, and Dilemmas. River Edge: World Scientific Publishing Company.

Feller, B. (2011). Countering China, Obama Asserts US a Pacific Power. Yahoo News. http://news.yahoo.com/countering-china-obama-asserts-us-pacific-power-234612474.html

Hieronymi, O. (2004). Global Challenges: The Atlantic Community and the Outlook for International Order. Bradford: Emerald Group Publishing Limited.

Huang, J. (2006). Passive US Strategy Could Be Upgraded. People’s Daily. http://english.peopledaily.com.cn/200605/12/eng20060512_264998.html

Krauss, E. S. (2003). Beyond Bilateralism: U.S.-Japan Relations in the New Asia-Pacific. Palo Alto: Stanford University Press.

Robinson, T. W. (1982). The Soviet Union and Asia in 1981. Asian Survey, 22, 13-32. http://dx.doi.org/10.2307/2643707

Ross, R. S. (2002). Navigating the Taiwan Strait: Deterrence, Escalation Dominance, and U.S.-China Relations. International Security, 27, 48-85. http://dx.doi.org/10.1162/016228802760987824

Saunders, P. C. (2000). Supping with a Long Spoon: Dependence and Interdependence in Sino-American Relations. The China Journal, 43, 55-81. http://dx.doi.org/10.2307/2667532

Shambaugh, D. (1988). Anti-Americanism in China. Annals of the American Academy of Political and Social Science, 497, 142-156. http://dx.doi.org/10.1177/0002716288497001012

Shambaugh, D. (2006). Power Shift: China and Asia's New Dynamics. Ewing, NJ: University of California Press.

Swaine, M. D. (2000). Interpreting China's Grand Strategy: Past, Present and Future. Santa Monica, CA: Rand Corporation. 
The White House (2002). President Bush, Chinese President Jiang Zemin Discuss Iraq, N. Korea.

http://georgewbush-whitehouse.archives.gov/news/releases/2002/10/20021025.html

Wallace, K. (2001). Bush Pledges Whatever It Takes to Defend Taiwan. CNN.

http://edition.cnn.com/2001/ALLPOLITICS/04/24/bush.taiwan.abc/

Yuan, J. (2005). China Seethes at US-Japan “Meddling”. Asia Times.

http://www.atimes.com/atimes/China/GB24Ad01.html

Zoellick, R. B. (2005). Whither China: From Membership to Responsibility? Remarks to National Committee on U.S.-China Relations. http://2001-2009.state.gov/s/d/former/zoellick/rem/53682.htm 
Scientific Research Publishing (SCIRP) is one of the largest Open Access journal publishers. It is currently publishing more than 200 open access, online, peer-reviewed journals covering a wide range of academic disciplines. SCIRP serves the worldwide academic communities and contributes to the progress and application of science with its publication.

Other selected journals from SCIRP are listed as below. Submit your manuscript to us via either submit@scirp.org or Online Submission Portal.
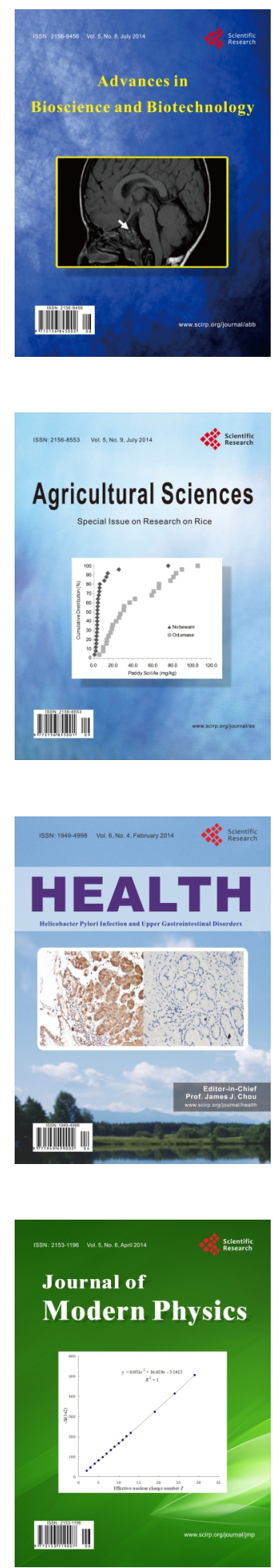
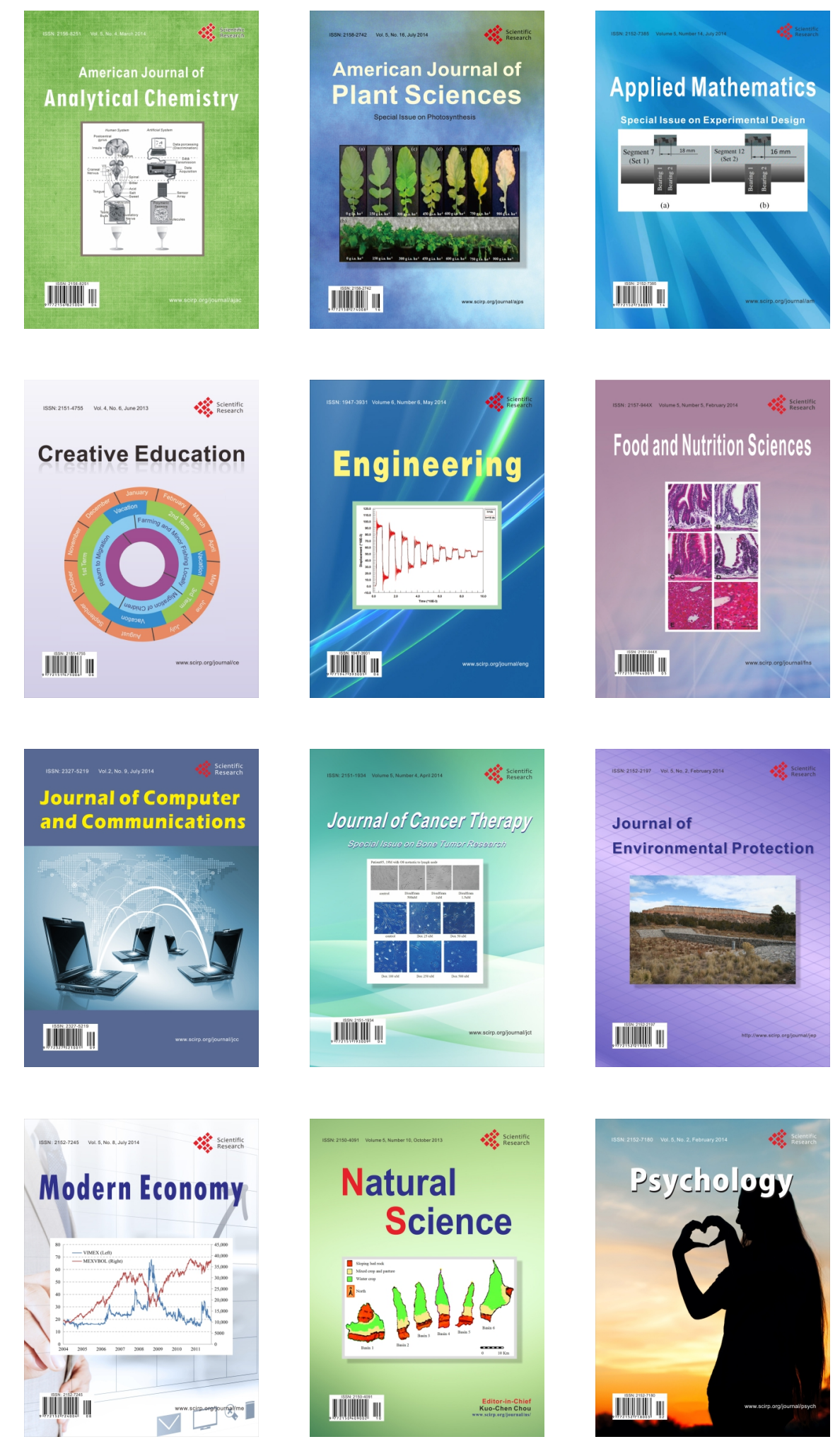